\title{
Penambahan Tepung Daun Singkong pada Pembuatan Nugget Jamur Merang
}

\author{
Chardina Dianovita $^{1^{*}}$, Praseptia Gardiarini ${ }^{2}$ \\ 1,2 Jurusan Perhotelan Politeknink Negeri Balikpapan \\ *chardina.dianovita@poltekba.ac.id
}

\begin{abstract}
This research is culinary art research which make nugget product with adding cassava and flour from cassava leaf. The purpose of this research are : 1) to find out the process of making merang mushroom nugget with the of cassava leaf powder addition, 2) to determine the colour test, aroma, texture and taste in making merangmushroom nuggets with the addition of cassava leaf powder, 3) to determine the test of color quality, texture, aroma and taste of the merang mushroom nugget with the addition of cassava leaf powder. This study consisted of two stages, namely experiments and organoleptic tests. The test involved 38 less trained panelists, then the results were analyzed using SPSS 24.0 for Windows. The Analysis results expressed interest with the highest test average result of the color hedonic was 3.87, aroma was 4.03, texture was 3.79, and taste was 4.18. Meanwhile, the average results of the highest value of color hedonic quality test that express interested was 4.21, aroma was 3.76, taste was 3.89 , and texture 3.53 was less interested. Of the two formulas most favored by panelists is F2 by adding 50 grams powder.
\end{abstract}

Keywords: Merang Mushroom Nugget (Volvariella Volvacea), Cassava Leaf Powder (Manihot Utilissima).

\begin{abstract}
Abstrak
Penelitian ini merupakan penelitian diranah boga dengan membuat produk nugget jamur. Pembuatan nugget jamur merang dengan penambahan tepung daun singkong sebagai diversifikasi produk nugget yang berasal dari bahan nabati. Adapun tujuan penelitian ini: 1) untuk mengetahui proses pembuatan nugget jamur merang dengan penambahan bubuk daun singkong, 2) untuk mengetahui uji kesukaan warna, aroma, tekstur dan rasa pada pembuatan nugget jamur merang dengan penambahan bubuk daun singkong, 3) untuk mengetahui uji mutu warna, tekstur, aroma dan rasa nugget jamur merang dengan penambahan bubuk daun singkong. Penelitian ini terdiri dari dua tahap yaitu eksperimen dan uji organoleptik. Pengujian melibatkan 38 orang panelis agak terlatih, kemudian hasilnya dianalisa menggunakan SPSS 24.0 For Windows. Hasil rata-rata tertinggi uji hedonik warna dengan nilai 3.87 menyatakan suka, aroma 4.03 menyatakan suka, tekstur 3.79 menyatakan suka, rasa 4.18 menyatakan suka. Sedangkan hasil rata rata tertinggi uji mutu hedonik warna dengan nilai 4.21 menyatakan suka, aroma 3.76 menyatakan suka, tekstur 3.53 menyatakan agak suka, rasa 3.89 menyatakan suka. Dari kedua formula yang paling disukai panelis adalah $\mathrm{F} 2$ dengan penambahan 50 gram tepung.
\end{abstract}

Kata Kunci: Nugget Jamur Merang (Volvariella Volvacea), Bubuk Daun Singkong (Manihot Utilissima)

\section{Pendahuluan}

Salah satu cara untuk mempertahankan mutu dan memperlama masa simpan daging adalah dengan membuat nugget, membuat nugget melalui beberap tahapan yaitu menggiling daging, kemudian membumbui setelah itu dilumuri dengan tepung roti (breading) dan digoreng setengah matang kemudian dibekukan (Astawan, Made, Wresdiyati, 2004). Pengolahan nugget tergolong mudah dan hanya membutuhkan waktu yang sedikit yaitu 1-3 menit hal ini karena nuget telah dimasak setengah matang pada awal pengolahanya(Justisia W.A dan Adi C.A, 2016).

Produk nugget tergolong jenis makanan siap saji yaitu produk yang dimasak setengah matang(preecooked) dan dibekukan. Tidak perlu memerlukan waktu yang lama untuk menggorengnya yaitu sekitar 1 menit dengan suhu $150^{\circ} \mathrm{C}$, warna nugget akan menjadi 
kekuningan dan kering. Tekstur nugget mengikuti bahan dasarnya, apabila bahan dasarnya padat maka tekstur nugget juga akan padat. Pertama kali nugget dibuat dan dipopulerkan di Amerika Serikat dimana kondisi masyarakatnya sangat sibuk sehingga banyak yang meminati produk ini (Ginting N dan Umar N, 2005).

Masyarakat telah menggunakan jamur untuk dikonsumsi karena memiliki kandungan gizi yang tinggi. Masyarakat membudidayakan jamur karena dapat dimakan dan sebagianya berkhasiat sebagai obat. Salah satunya adalah jamur merang(Volvariella volvacea) yang bercitarasa enak sehingga dapat dikomersilkan oleh petani, bahkan tak jarang pengusaha agribisnis Indonesia yang membudidayakan jamur tersebut(Sumiati E dan Djuariah S, 2007).

Daun singkong berasal dari ketela pohon yang berbentuk lancip dan bertangkai kemerahan. Tanaman ini banyak tumbuh di Indonesia karena merupakan daerah dengan iklim tropis, daun ini banyak dimanfaatkan untuk bahan pangan. Daun singkong juga cocok dijadikan sayur karena kandungan gizinya yang tinggi, namun dalam mengolahnya tidaklah mudah, karena teksturnya yang kurang lembut sehingga perlu pengolahan khusus agar lebih mudah diterima oleh lidah semua orang. Biasanya orang Indonesia menggunakan santan untuk mengolah daun singkong. Mayarakat banyak yang mengkonsumsi daun singkong contohnya orang Minangkabau yang selalu menjadikan daun singkong sebagai pelengkap makanan. Disamping kaya gizi daun singkong juga murah dan mudah didapatkan (Mandriali, Berlio., Usman Pato., Johan, 2016).

Pembuatan nugget jamur merang dengan penambahan tepung daun singkong merupakan alternative pilihan makanan yang dapat dijadikan santapan oleh seorang vegetarian. Jamur merang memiliki kandungan gizi yang baik ditambah dengan tepug daun singkong dapat memperkaya mineral yang terdapat pada nugget tersebut. Daun singkong memiliki kandungan flavonoid dan fenolik yang cukup baik yang dapat digunakan sebagi antioksidan dalam tubuh(Hasim Syamsul dan Kusuma Dewi, 2018).

Oleh karena itu penulis memanfaatkan jamur merang dan daun singkong yang dibuat bubuk untuk bahan dasar pembuatan nugget. Nugget merupakan salah satu makanan yang digemari oleh banyak kalangan terutama anak-anak, nugget ini cocok untuk vegetarian, anak-anak yang susah makan sayur, baik sebagai camilan atau dijadikan lauk teman makan nasi. Selain karena mudah didapatkan, rasanya yang enak dan cara mengonsumsinya yang tergolong mudah. Sedangkan daun singkong harga jual yang murah dan mudah didapatkan dan pemanfaatan masih kurang. Oleh sebab itu, peneliti tertarik untuk membuat nugget dengan bahan dasar jamur merang. Penulis juga menambahkan bubuk daun singkong sebagai penambah serat pada nugget dan memberi warna pada nugget.

\section{Metodologi}

Penelitian ini merupakan jenis penelitian kuantitatif eksperimen dengan menggunakan dua tahap penelitian yaitu, tahap pertama penelitian pendahuluan dan tahap kedua penelitian lanjutan.Penelitian pendahuluan dilakukan untuk menguji standar resep produk (resep acuan) nugget jamur tiram. Pada tahap ini penelitian yang digunakan adalah eksperimen. Dari resep acuan ini penulis mengganti jamur tiram dengan jamur merang dan mengurangi pengunaan tepung terigu dengan penambahan bubuk daun singkong. Jenis penelitian lanjutan yang penulis pakai adalah uji organoleptik, yaitu uji yang menggunakan indera, baik indera penglihatan, indera pencicipan, indera pembauan, dan indera perabaan atau panelis (Sugiyono, 2012). 


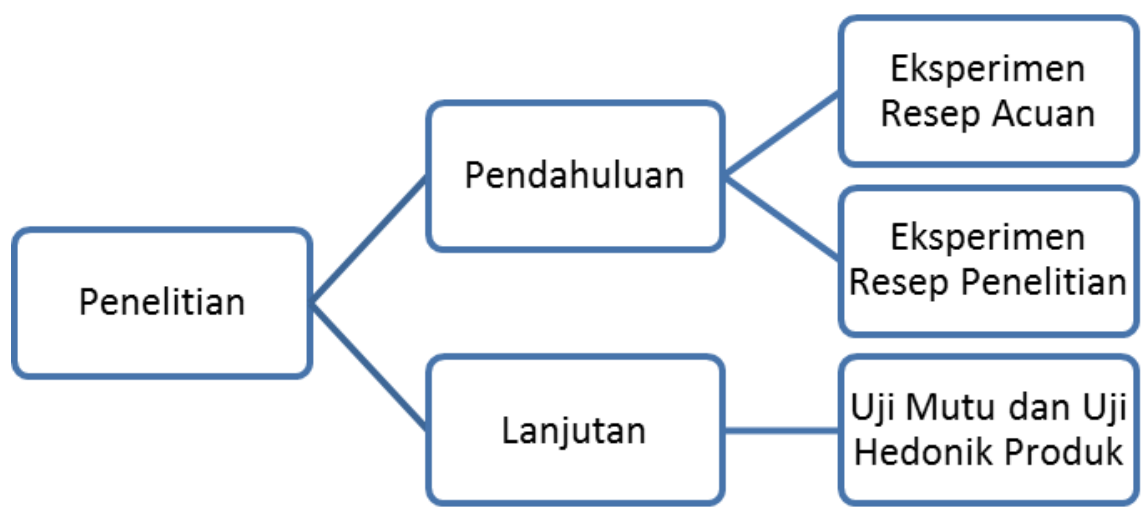

Gambar 1 Bagan metodologi penelitian

Penelitian pendahuluan dengan metode eksperimen menggunakan alat antara lain timbangan digital, loyang,kompor, steamer dan pisau dengan bahan berupa jamur merang, tepung daun singkong, tepung terigu dan bumbu-bumbu. Sedangkan untuk penelitin lanjutan instrument yang digunakan adalah kuesioner uji mutu dan uji hedonik produk.

\section{Hasil dan Pembahasan}

Proses pembuatan pada nugget jamur merang dengan penambahan bubuk daun singkong diawali dengan pembuatan bubuk daun singkong dan menggunakan acuan resep nugget jamur tiram, penulis uji coba resep dan melakukan 2 kali eksperimen. Sebelum melakukan ekperimen penulis melakukan uji coba resep acuan nugget jamur tiram dan hasil dari resep acuan dari segi tekstur, rasa, aroma dan warna ternyata layak untuk dijadikan sebagai resep acuan terhadap produk yang akan penulis eksperimen.

Eksperimen pertama yang di lakukan dengan mengurangi penggunaan tepung terigu yang awalnya 100 gram dibagi dengan penambahan bubuk daun singkong sebanyak $25 \%$ atau sama dengan F1 sebanyak 25 gram berdasarkan hasil dari eksperimen ini tekstur, aroma, rasa sudah sesuai dengan kriteria nugget yang baik tetapi dari aspek warna eksperimen ini warna nugget tidak terlalu hijau lumut. Eksperimen pertama memiliki kurang dari aspek warna maka dilakukan eksperimen kedua agar nugget jamur merang yang dihasilkan dapat lebih hijau lumut.

Eksperimen kedua yang di lakukan dengan mengurangi penggunaan tepung terigu yang awalnya 100 gr di bagi dengan penambahan bubuk daun singkong sebanyak $50 \%$ atau sama dengan F2 sebanyak 50 gram. Berdasarkan hasil dari eksperimen ini nugget jamur merang dengan penambahan bubuk daun singkong bila dilihat dari aspek warna, aroma, tekstur, dan rasa produk dari eksperimen ini sudah sesuai dengan kriteria nugget yang baik, penulis sudah mendapat resep acuan nugget jamur merang dengan penambahan bubuk daun singkong yang akan penulis gunakan untuk uji organoleptik kepada panelis untuk mengetahui perbandingan pada 2 sampel. 


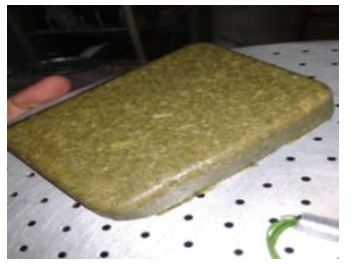

A

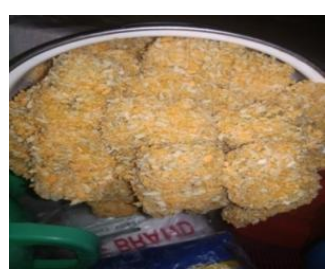

B

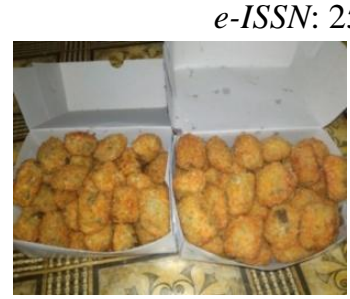

$\mathrm{C}$

A. Formula 1

B. Formula 2

C. Formula 1 dan Formula 2 setelah digoreng

Gambar 2 Formula nugget sebelum dan sesudah digorng.

Berdasarkan hasil penyebaran angket ke 38 panelis agak terlatih hasil uji hedonik menunjukan bahwa nilai rata-rata dari aspek warna dengan rata-rata $F 1$ : 3,87 pada dan $F 2$ : 3,87, panelis menyatakan sama-sama suka dengan kedua warna dari nugget jamur merang yang berwarna hijau lumut. Warna hijau lumut didapatkan karena kombinasi jamur merang yang berwana coklat tua keabu-abuan dan bubuk daun singkong yang berwarna hijau sehingga mendaptakan hasil warna hijau lumut/moss.

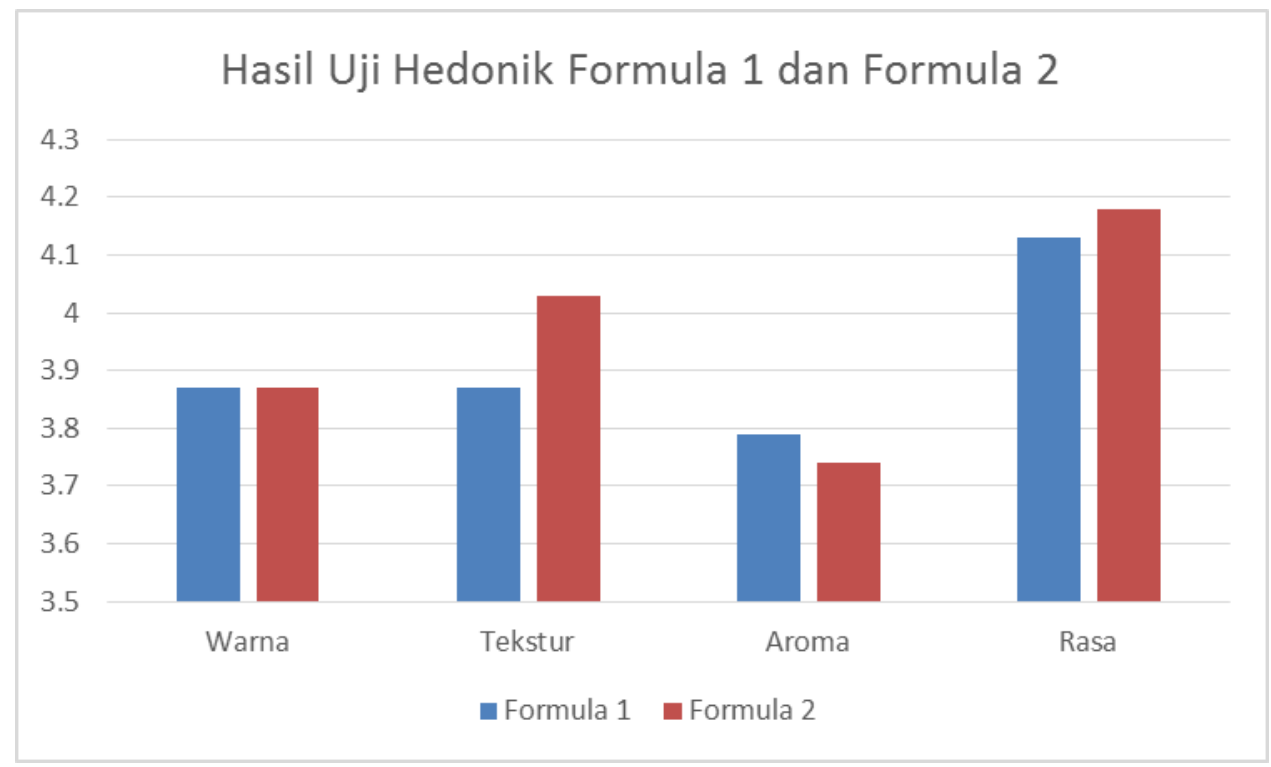

Gambar 3. Diagram Hasil Uji Hedonik Formula 1 dan Formula 2

Dari aspek aroma didapatkan nilai rata-rata yang menunjukan F1: 3,87 dan F2: 4,03, yang menunjukkan bahwa panelis lebih menyukai pada F2 yang menyatakan suka,dengan penambahan bubuk daun singkong pada F2 yang lebih banyak sehingga aroma khas daun singkong lebih tercium.Dari aspek tekstur didapatkan nilai rata-rata F1: 3,79 dan F2: 3,74, yang menunjukan di kategori sama-sama suka akan tetapi nilai yang lebih tinggi bahwa panelis menyukai F1, karena penggunaan tepung terigu yang lebih banyak pada F1 sehingga tekstur lebih padat dibandingankan dengan F2. Dari aspek rasa didapatkan nilai rata-rata yang menunjukan F1 4,13 dan F2 4,18, yang menunjukkan bahwa panelis sama-sama di kategori suka antara F1 dan F2, hal ini karena rasa gurih dan berasa daun singkong yang terdapat pada nugget. Rasa gurih pada nugget dihasilkan karena penggunaan garam dan penyedap rasa yang memberi efek gurih pada nugget. 
Bedasarkan total rekapitulasi rata-rata tingkat kesukaan dari angket yang diberikan ke panelis dapat diketahui nugget jamur merang dengan penambahan bubuk daun singkong yang paling disukai oleh panelis adalah F2 sebesar 50 gram. Panelis lebih menyukai nugget yang berwarna hijau lumut dan lebih berasa daun singkong sehingga panelis lebih banyak memilih nugget jamur merang dengan lebih banyak campuran bubuk daun singkong.

Berdasarkan hasil uji mutu hedonik menunjukan bahwa dari aspek warna dengan nilai rata-rata F1:3,71 dan F2: 4,21 yang menunjukkan nilai rata-rata yang lebih tinggi adalah F2 yang menyatakan berwarna hijau lumut. Warna dari F2 lebih berwarna hijau lumut karena penambahan bubuk daun singkong yang lebih banyak dibandingkan F1. Warna hijau lumut didapatkan karena kombinasi jamur merang yang berwana coklat tua keabu-abuan dan bubuk daun singkong yang berwarna hijau sehingga dihasilkan warna hijau lumut. Oleh karena itu, dapat disimpulkan bahwa warna nugget yang dihasilkan dalam penelitian ini telah sesuai dengan standar mutu warna nugget yang diharapkan yaitu berwarna hijau lumut.

Dari aspek aroma didapatkan nilai rata-rata F1: 3,42 dan F2: 3,76 yang menunjukan bahwa nilai rata-rata yang lebih tinggi adalah F2 yang menyatakan beraroma daun singkong. Hasil ini didukung Penelitian oleh Sitepu (2018) yang menyatakan bahwa nugget dalam penelitian tersebut sudah mampu dalam menghasilkan aroma yang sesuai dan disukai oleh panelis dengan bahan dasar produknya yang alami tanpa ada bahan tambahan. Oleh karena itu dapat disimpulkan bahwa nugget jamur merang dengan penambahan bubuk daun singkong telah memenuhi standar aroma yang diharapkan yaitu beraroma bubuk daun singkong(Sitepu., 2018).

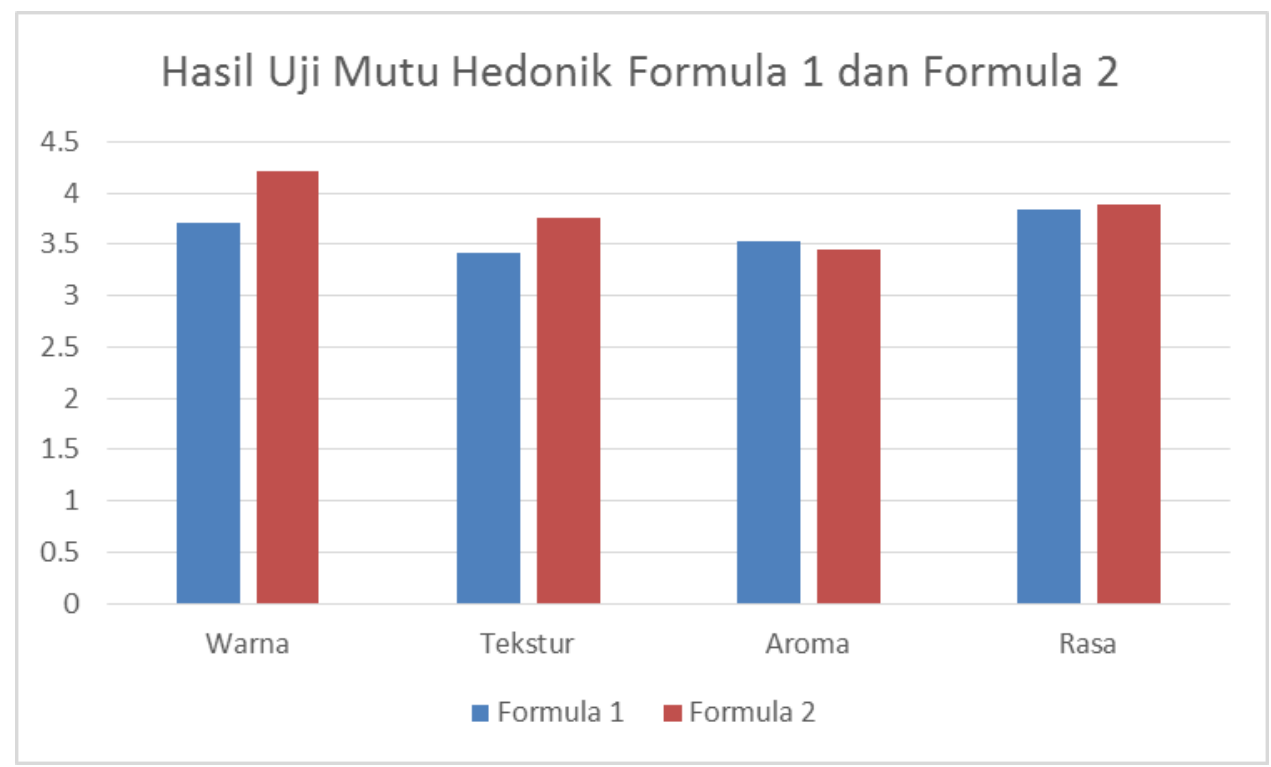

Gambar 4. Diagram Hasil Uji Mutu Hedonik Formula 1 dan Formula 2

Dari aspek tekstur didapatkan nilai rata-rata F1: 3,53 dan F2: 3,45 yag menunjukkan rata-rata tertinggi ada pada F1 yang menyatakan padat. Hasil ini didukung oleh penelitian Raskita Saragih (2015) menunjukkan bahwa jumlah yang tepat dari bahan pengisi dan sifat emulsifier dari telur menyebabkan tekstur nugget menjadi padat dan kompak serta tambahan bumbu-bumbu yang menyebabkan tekstur nugget menjadi padat dan kompak.(Wulandari, Suryaningsih, Pratama, \& Putra, 2016) Oleh karena itu dapat disimpulkan bahwa nugget jamur merang dengan penambahan bubuk daun singkong telah memenuhi standar tekstur yang diharapkan yaitu bertekstur padat(Saragih R, 2015).

Dari aspek rasa didapatkan nilai rata-rata $\mathrm{F} 1$ : 3,84 dan $\mathrm{F} 2$ : 3,89 yang menunjukkan bahwa panelis sama-sama di kategori suka antara F1 dan F2, hal ini karena rasa gurih dan berasa daun 
singkong yang terdapat pada nugget. Hasil ini didukung oleh penelitian Herly Evanuarini (2010) bahwa rasa gurih pada nugget dihasilkan karena penambahan garam dan penyedap rasa serta bumbu-bumbu lainnya karena selain berfungsi sebagai pengawet, garam juga berfungsi sebagai penambah cita rasa pada pangan. Oleh karena itu dapat disimpulkan bahwa nugget jamur merang dengan penambahan bubuk daun singkong telah memenuhi standar rasa yang diharapkan yaitu berasa gurih dan berasa daun singkong(Herly Evanuary, 2010).

Bedasarkan total rekapitulasi rata-rata uji mutu hedonik dari angket yang diberikan ke panelis dapat diketahui nugget jamur merang dengan penambahan bubuk daun singkong memiliki mutu terbaik oleh panelis adalah F2 sebanyak 50 gram karena menurut panelis dari aspek warna lebih berwarna hijau lumut, dari aspek aroma pada sampel ini lebih beraroma daun singkong dan rasa lebih terasa dari bubuk daun singkong tersebut, sehingga panelis lebih banyak memilih nugget jamur merang pada sampel ini.

\section{Kesimpulan}

Penulis perlu melakukan beberapa kali eksperimen untuk dapat menemukan formula resep yang tepat dari segi teknik aroma, tekstur, rasa, dan warna terhadap produk nugget jamur merang dengan penambahan bubuk daun singkong.Penelitian yang dilakukan masih sampai tahap uji organoleptik untuk 2 formula nugget jamur merang dengan penambahan bubuk daun singkong

\section{Saran}

Setelah ditentukan mutu terbaik dari 2 formula nugget jamur merang dengan penambahan bubuk daun singkong, penelitian selanjutnya dapat menganalisis kadar zat besi (Fe) dan kadar sianida $(\mathrm{CN})$ yang tergandung pada produk nugget ini.

\section{Ucapan Terimakasih}

Penelitian ini didanai oleh DIPA Poltekba Tahun Anggaran 2019 dengan nomor kontrak :0538/PL32/PP/2019.Terimakasih kami sampaikan kepada Pusat Penelitian dan Pengabdian kepada Masyarakat Politeknik Negeri Balikpapan atas dukungan dana yang diberikan sehingga penelitian ini bisa terlaksana

\section{Daftar Pustaka}

Astawan, Made, Wresdiyati, T. (2004). Diet Sehat dengan Makanan Berserat. Solo: Tiga Serangkai.

Ginting N dan Umar N. (2005). Penggunaan Bahan Pengisi pada Nugget Itik Air. Jurnal Agribisnis Dan Peternakan, 1(3).

Hasim Syamsul dan Kusuma Dewi. (2018). Effect of Boiled Cassava Leaves ( Manihot esculenta Crantz) on Total Phenolic, Flavonoid and its Antioxidant Activity. MANAJEMEN IKM - Jurnal Manajemen Pengembangan Industri Kecil Menengah, 3(3), 116-127. https://doi.org/10.29244/1-12

Herly Evanuary. (2010). Kualitas Chiken Nugget Dengan Penambahan Putih Telur. Jurnal Ilmu Dan Teknologi Hasil Ternak., 17-22.

Justisia W.A dan Adi C.A. (2016). Peningkatan Daya Terima dan Protein Nugget Subtitusi Ikan Lele(Clariasbatrachus)dan Kacang Merah(Vignaangularis). Gizi Media Indonesia, 11(1), 106-112.

Mandriali, Berlio., Usman Pato., Johan, S. V. (2016). Penambahan Tepung Daun Singkong Dalam Pembuatan Kerupuk Sagu. Universitas Riau.

Saragih R. (2015). Nugget Jamur Tiram (Pleuretus ostreatus) sebagai Alternatif Pangan Sehat Vegetarian. E-Journal Widya Kesehatan Dan Lingkungan, 1(2), 90-95. 
Sitepu., S. U. M. (2018). Pemanfaatan Ikan Bandeng (Chanos Chanos Forrskal) Wortel dan Jagung Manis pada Pembuatan Nugget, Kandungan Gizi dan Daya Terima. Univeritas Sumatra Utara.

Sugiyono. (2012). Metodologi Penelitian Kuantitatif dan Kualitatif R\&D. jakarta: Alfabeta.

Sumiati E dan Djuariah S. (2007). Teknologi Budidaya dan Penanganan Pascapanen Jamur Merang, Volvariella Volvacea. Bandung: Balai Penelitian Tanaman Sayuran.

Wulandari, E., Suryaningsih, L., Pratama, A., \& Putra, D. S. (2016). Karakteristik Fisik, Kimia dan Nilai Kesukaan Nugget Ayam Dengan Penambahan Pasta Tomat ( Effect of Tomatos Paste to Physicochemical and Sensory Characteristics Chicken Nuggets ). Jurnal Ilmu Ternak, 16(2), 95-99. 